Journal of Business Management and
Economic Research
2018, 2(12): 37-42 DOI: 10.29226/TR1001.2019.96
Journal Homepage: https://www.jobmer.org

\title{
The Role of Investment and Development Road Traffic Infrastructure for Vietnam's Economic Development
}

\author{
Cu Thanh Thuy \\ Hanoi Architectural University, Vietnam thanhthuyktdt85@gmail.com
}

\begin{abstract}
This study was carried out to analyze the current situation of investment in road traffic infrastructure development in Vietnam, thus analyzing the contribution of investment in development of road infrastructure with Vietnam's economy development. To analyze the role of investment and development road traffic infrastructure for Vietnam's economic development, researchers used modeling method to analyze the role on,then to propose a number of recommendations to contribute to further enhance the role of investment in road traffic infrastructure development with the Vietnam's Economic Development
\end{abstract}

Keywords: Road traffic, development and investment, road traffic infrastructure, economic development, Vietnam

\section{Introduction}

Investment in the development of road traffic infrastructure is an important part of investment in general, the results of investment in the development of road traffic infrastructure are the road traffic infrastructure system complete, contribute to promoting traffic between the local as well as between countries, thereby contribute to the promoting growth and economic development of each country.

In addition, investment in road traffic infrastructure constructionis part of the total investment of the whole society, therefore, like other investments, investment in the development of road traffic infrastructure also has a direct impact on the economic development of each country.

In particular, when a traffic project is constructed, it generates income for the construction enterprises which joined the project, its also create jobs and income for employees. Then these enterprises and employees use their income to buy goods and services. Thus they contribute to increased productivity and GDP per capita of the economy. Just like that will have an increased production chain, employment and GDP per capita.

For such reasons, this research analyzes the role of investment in the road traffic infrastructure development with economic development in Vietnam, it points out the achievements, constraints and recommendations that contribute to enhancing the role of investment in development of road traffic infrastructure with economic development of Vietnam. 
Journal of Business Management and Economic Research, vol.2, issue.12, pp.37-42

\section{Overview of Research}

Investment in transport infrastructure with economic growth and development has received not only the attention of policymakers but also of researchers around the world.

The research by Glen Weisbrod (2009) on the economic impact of public investment on transport has shown that the development of transport will help to save production costs and create mobility in economic activity, creating jobs, growth for the economy...Investments in the transport system will have an impact in the long term, so it needs to seriously consider the benefits, costs and investment levels for optimal traffic.

Similar to the view of Glen Weisbrod (2009), Susan Handy (2005), in her research showed necessary requirement of investing the transport system which focus system construction of highway, Susan Handy said that the construction of the highway system would contribute to the development of shopping centers, tourism development, It helps to reduce production costs, increase economic growth and increase the aspirations of the urban population to live in the suburbs

Meanwhile, Pham Thi Tuyet (2015) has a different approach when it comes to practical development of road traffic Vietnam in the previous period and propose capital requirements for developing road traffic in the coming period (forecast for investment capital till 2020), the author also pointed out that the current investment in transportation infrastructure focuses on three main sources: Foreign loans, Government bonds and mobilized from the State budget, the results and limitations are also the author pointed out, then to propose a number of recommendations aimed at developing road traffic system in Vietnam.Similar approach of Pham Thi Tuyet but not forecasted capital requirements for road traffic in the coming period, Pham Dinh Hanh (2016) uses data from the Ministry of Transport on the current situation of investment in transport infrastructure development to analyze the achievements and limited aspects to propose recommendations to contribute to further improve the investment activity and development of transport infrastructure in Vietnam.

There is a relative similarity in the problem approach as well as the use of statistical methods to describe and interpret research results with Pham Thi Tuyet (2015), with data from the annual review reports of the Ministry of Transport, Vu Dinh Anh (2016) in his study analyzed the need for capital for investment in road traffic infrastructure development.The author also points out that, experiences of countries around the world show that, there are three main sources of capital to be mobilized for the development of transport infrastructure: (1) investment from the state budget; (2) Domestic mobilized capital (through the banking system, enterprises, issuance of bonds ...); (3) Capital mobilized from foreign countries (international loans, international bonds, foreign direct investment ...). Simultaneously, the research also pointed out that due to limitations on the size of the state budget so most of the capital investment in the development of infrastructure in developing countries in Asia are mobilized from abroad (primarily ODA) and private investors at domestic and abroad.

Also selected object of study is the transport infrastructure system of Vietnam as previous studies of Vu Dinh Anh (2016), Nguyen Van Bay (2016), Pham Thi Tuyet (2015), However, research team of Tran Dinh Thien and Vinh Tuong (2016) focused on the development of transport infrastructure in Vietnam to meet the requirements of industrialization and modernization in the context of international economic integration., the new context has been focus on explored by the authors. The study analyzes successes and limitations in transport infrastructure development in Vietnam, the development of enterprises in transport infrastructure has also been analyzed by the research team, the author also pointed out the development in both quantity and quality of these enterprises in the author's research period. 
Challenges in road traffic infrastructure development have also been mentioned, on the basis of which the author has proposed proposals to clear the capital for transport infrastructure development in Vietnam, one of the important areas is the road traffic infrastructure development. Specifically, the author analyzes the strategy of transport infrastructure development, priorities and roadmap for investment in transport infrastructure; solutions have also been pointed out for the development of transport infrastructure in Vietnam in the context of international economic integration today.

\section{Research methodology}

The data for the research was collected from the annual review reports of the Ministry of Transport, General Statistics Office, data from scientific works published in scientific journals in domestic and abroad, some data are collected such as: Investment capital for development of road traffic infrastructure, GDP per capita of Vietnam in the period 2001-2016, ...With the data collected, the research uses a descriptive statistical method to analyze the dynamics of Vietnam's investment in road traffic infrastructure development. The relationship between investment in road traffic infrastructure development and economic development is quantified through the quantitative model with the dependent variable GDP per capita; it represents the economic development and the investment capital for the development of road traffic infrastructure - representing the investment in the development of road traffic infrastructure.

\section{Research Findings}

The actual situation of investment in the development of road traffic infrastructure in Vietnam is as follows:Investment capital for Highway (excluding Highway 1 and the HCMroad) fluctuating around 255701 invested billion, on average 31963 billion / year, which, nonbudgetary capital of VND17,023 billion and VND 84,222 billion have not been found.

Table 1: Capital investment in upgrading national roads (not including the Ho Chi Minh road and Highway 1 )

Unit: VND billion

\begin{tabular}{|c|c|c|c|c|}
\hline No & Source & $2012-2020$ & $2012-2015$ & $2016-2020$ \\
\hline 1 & ODA & 92.956 & 66.297 & 26.659 \\
\hline 2 & State budget & 16.908 & 12.711 & 4.197 \\
\hline 3 & Government Bonds & 44.592 & 23.850 & 20.742 \\
\hline 4 & Off-budget funds & 17.023 & 10.711 & 6.313 \\
\hline 5 & No source & 84.222 & 19.822 & 64.400 \\
\hline & Sum & 255.701 & 133.391 & 122.311 \\
\hline
\end{tabular}

Source: Decision No. 355 to adjust the Transport Development Strategy of Vietnam to 2020 with a vision to 2030

Investment capital for development of National Highway 1 is VND 89362 billion for the whole period, VND 22340 billion for the whole year, VND 240839 billion for the Ho Chi Minh road, VND 26760 billion per year. In 2012-2015, the total investment capital for upgrading national highways in Vietnam is about 133391 billion dong, which accounts for most of the state capital with the contribution of state budget capital (about VND 12711 billion) official development assistance (VND 66297 billion) and government bond capital (VND23850 billion) Renovation 
project, expansion and upgrading of National Highway 1 and Ho Chi Minh road as key projects in the period 2012-2020, funding for the implementation of this project are as follows:

Table 2: Capital for upgrading and expansion of National Road No.1, Ho Chi Minh road

Unit: VND billion

\begin{tabular}{|l|l|l|l|l|}
\hline No & \multicolumn{1}{|c|}{ Road name } & \multicolumn{1}{|c|}{ Tổng } & \multicolumn{1}{|c|}{$\mathbf{2 0 1 2 - \mathbf { 2 0 1 5 }}$} & \multicolumn{1}{|c|}{$\mathbf{2 0 1 6}$ - 2020 } \\
\hline 1 & Highway 1 & 89.362 & 67.022 & 22.340 \\
\hline 2 & Ho Chi Minh road & 240.839 & 69.997 & 170.842 \\
\hline
\end{tabular}

Source: Decision No. 355 to adjust the Transport Development Strategy of Vietnam to 2020 with a vision to 2030

*) The role of investment in development of road traffic infrastructure with economic development in Vietnam

Research using OLS regression model to analyze the role of investment in infrastructure development road with economic development in Vietnam, firstly, the authors examine the appropriateness of regression models and some defects of the model:

\section{Table 3: Summary of model parameters}

Model Summary

\begin{tabular}{|c|c|c|c|c|}
\hline Model & $\mathrm{R}$ & R Square & $\begin{array}{c}\text { Adjusted R } \\
\text { Square }\end{array}$ & $\begin{array}{l}\text { Std. Error of the } \\
\text { Estimate }\end{array}$ \\
\hline 1 & $.835^{\mathrm{a}}$ & .697 & .675 & 366.460 \\
\hline
\end{tabular}

a. Predictors: (Constant), VDT

\section{Source: Calculated results of the author}

With R Square $=0.667$, the independent variables in the model account for about $66.7 \%$ of the dependent variable.

Table 4: Analysis of Variances (ANOVA)

ANOVA $^{a}$

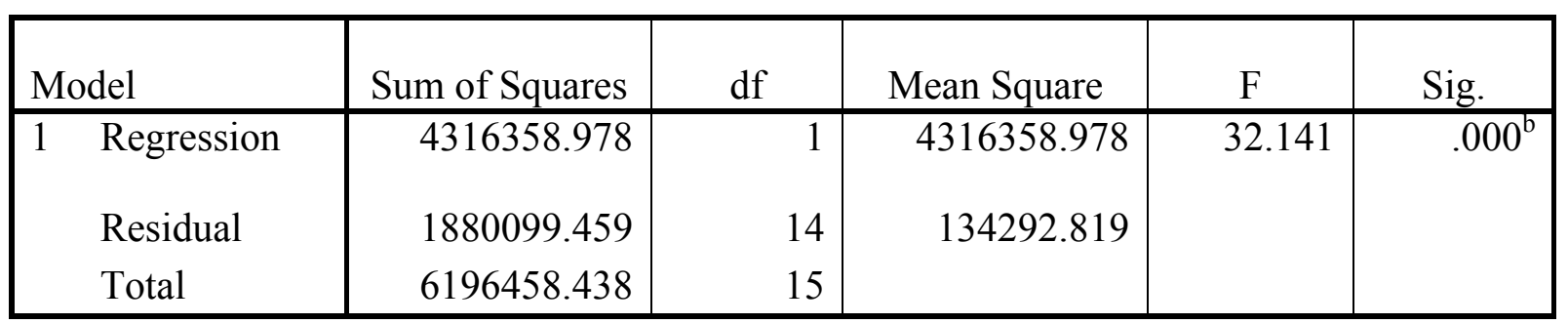

a. Dependent Variable: GDPnguoi

b. Predictors: (Constant), VDT

Source: Author's calculations

Results from the data table show that, with coefficient Sig $=0.000$; Tested F $=32,141$, so the research model is suitable. 
Journal of Business Management and Economic Research, vol.2, issue.12, pp.37-42

Table 5: Regression coefficients

Coefficients ${ }^{a}$

\begin{tabular}{|c|c|c|c|c|c|}
\hline \multirow[b]{2}{*}{ Model } & \multicolumn{2}{|c|}{ Unstandardized Coefficients } & \multirow{2}{*}{$\begin{array}{c}\begin{array}{c}\text { Standardized } \\
\text { Coefficients }\end{array} \\
\text { Beta }\end{array}$} & \multirow[b]{2}{*}{$\mathrm{t}$} & \multirow[b]{2}{*}{ Sig. } \\
\hline & B & Std. Error & & & \\
\hline 1 (Constant) & 68.374 & 215.436 & & .317 & .756 \\
\hline VDT & 57.688 & 10.175 & .835 & 5.669 & .000 \\
\hline
\end{tabular}

a. Dependent Variable: GDPnguoi

Source: Author's calculations

The results of the analysis showed that, to invest in the development of the road traffic infrastructure (the scale used is investment capital), which is closely related to economic development (the used scale is the GDP per capita annually). The beta adjusted to 0.835 , this suggests that investment in infrastructure development of road traffic impacts directly or indirectly to economic development and this is particularly effective with the local difficulties, remote areas, thus creating the economic development of the locality.

\section{Recommendations}

To better promote the role of investment in roads tracffic infrastructure development creates positive change with economic development of the locality in particular and Vietnam in general, a number of recommendations, the authors suggest as follows: It is necessary to select the right investment projects for development of road traffic infrastructure: Priority should be given to key area investment, remote areas in order to promote the economic growth and development of the difficult localities. It is necessary to build and train a contingent of cadres directly involved in investment in the development of road traffic infrastructure from project construction to project disbursement. Increase the level of specialization and reduce plurality of the State management to get good experts, assume its role and responsibilities in the management of the State for investment projects in infrastructure development of road traffic. To use and mobilize effectively the investment capital sources for the development of road traffic infrastructures, contributing effectively to raising the quality of investment in the road traffic infrastructures development, contributing to reduce pressure for the State budget capital for investment and development of road traffic infrastructure, thereby contributing to economic and social development of the country. 
Journal of Business Management and Economic Research, vol.2, issue.12, pp.37-42

\section{References}

Alfredo Marvao Pereira, Jorge M. Andraz (2010), "On the economic effects of public infrastructure investment: A survey of the international evidence", college of William and mary department of economics, working paper 108, december 2010

Glen Weisbrod(2009), Economic impact of public transportation investment, American public transportation association.

Nguyen Van Vinh (2016), "Mobilizing capital for infrastructure development", Proceedings conference on Transportation, Ministry of Transport.

Investment and development of transportation infrastructure: Reality and Solutions ", Journal of Communist, April issue

Pham Thi Tuyet (2015), "The Reality and needs of capital for development of road traffic in Vietnam", Journal of Traffic

Susan Handy (2005), "Smart growth and the transportation- land use connection: what does the research tell us?",Sage publications, vol 28, No2

Ta Van Khoai (2009), State management for projects construction investment from the State budget in Vietnam, PhD thesis, Ho Chi Minh National Academy of Politics and Public Administration.

Road Administration (2014), 2014 Road Traffic Statistics

Road Administration (2015), 2015 Road Traffic Statistics

Road Administration (2016), Road Traffic Statistics 2016

Tran Dinh Thien and Vinh Tuong (2016),"Development of transport infrastructure in Vietnam meet the requirements industrialization - modernization in the context of international economic integration ", Proceedings conference on Transportation, Ministry of Transport.

Tran Van Hong (2002), Renovation of management mechanism using capital construction investment of the State, PhD thesis, Academy of Finance.

Trinh Thi Thuy Hong (2012), Management of state budget expenditures in investment in capital construction in Binh Dinh province, PhD dissertation economics, National Economics University

Trịnh Văn Vinh (2000), The method of auditing the final settlement of capital construction works, PhD thesis, Hanoi University of Finance and Accounting

$\mathrm{Vu}$ Dinh Anh (2016),"The need for capital investment in the development of transport infrastructure"Proceedings conference on Transportation, Ministry of Transport. 